\title{
大和川流域における物質移動量の推定 ESTIMATION OF MASS FLOW IN THE YAMATOGAWA BASIN
}

\author{
窪原拓馬 1 -井伊博行 2 . 平田健正 ${ }^{3}$. 石塚正秀 4 - 谷口正伸 1 ・伊勢達男 5 •宮川勇二 6 \\ Takuma KUBOHARA, Hiroyuki II, Tatemasa HIRATA, Masahide ISHIZUKA, \\ Masanobu TANIGUCHI, Tatsuo ISE and Yuji MIYAGAWA \\ 1学生会員 和歌山大学大学院 システム工学研究科（テ640-8510 和歌山市栄谷930) \\ 2 正会員 博 (理) 和歌山大学教授 システム工学部（テ640-8510 和歌山市栄谷930) \\ 3 正会員 工博 和歌山大学教授 システム工学部（同上） \\ 4 正会員 博 (工) 和歌山大学助手 システム工学部（同上）

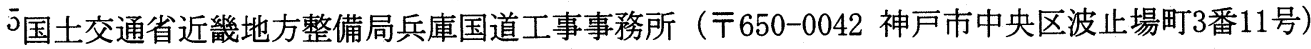 \\ 6 国土交通省近畿地方整備局大和川工事事務所（广582-0009 柏原市大正2-10-8）
}

\begin{abstract}
Daily mass flow values of COD, $\mathrm{Cl}$, T-P and $\mathrm{NO}_{3}^{-}$in the Yamatogawa basin could be calculated from daily flow rates because the mass flow values were proportionate to flow rate. Though flow rate was measured daily, the concentrations were measured once a month. Daily mass flow values of BOD and $\mathrm{NH}_{4}{ }^{+}$could not be estimated from daily flow rate however because the mass flow values of BOD and $\mathrm{NH}_{4}^{+}$didn't depend on flow rate but rather on water temperature. The calculated daily mass flow value of COD per number of people was high in the high density population area. The values of $\mathrm{Cl}^{-}$and $\mathrm{NO}_{3}{ }^{-}$per number of people were low but abnormally high in the high density population area. The values of T-P per the number of people and per area were high in the farmland area and low in both the forest area and the housing site. The values of $\mathrm{COD}, \mathrm{Cl}^{-}$and $\mathrm{NO}_{3}{ }^{-}$per area were high in the housing site.
\end{abstract}

Key Words : mass flow, flow rate, $\mathrm{COD}, \mathrm{Cl}, \mathrm{T}-\mathrm{P}, \mathrm{NO}_{3}^{-}-\mathrm{N}$

\section{1. はじめに}

わが国の河川の水質污濁は，1960年代後半から1970年 代にかけて，高度経済成長に伴ない，急激に進行したが, その後, 排水規制や下水道整備などの水質改善対策によ り，河川のBOD環境基準達成状況は年々上昇し，現在は， 全体としては，水質は改善されつつある ${ }^{1)}$. しかし，一 部の都市河川においては, 未だBOD環境基準の達成が困 難な流域もある. 本研究の対象地域である大和川もBOD 環境基準を未だ達成できない流域の一つである．大和川 のBODは，平成6年11月に策定された「大和川清流ルネッ サンス21」による水質改善施策により，近年，低下傾向 にあるが，平成 12 年度のBOD平均值は $6.7 \mathrm{mg} / 1$ で， BOD $75 \%$ 值では9. $3 \mathrm{mg} / 1$ と高く, 環境基準の $5 \mathrm{mg} / 1$ (河川C 類型)を達成しておらず，全国の一級河川のなかでワー スト 1 位である ${ }^{2), 3)}$ ，そのため，水質改善は依然，急務 の課題である. 本研究以前に, 水質改善対策の一環とし て, 支川の石川で土地利用と水質の関係 ${ }^{4}$ や河川水と地 下水の起源 ${ }^{5}$ について, また, 大和川全体を対象とした

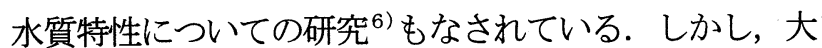
和川全体を対象とした研究では, 3 回の調查データから 考察しており，長期間の水質変化を考慮した大和川流域 の平均的な水質特性については把握できていない．

このことから，大和川流域の平均的な水質特性を把握 するために，1995年～1999年の 5 年間の水質，流量デー 夕を用いて，平均的な物質移動量と物質負荷量の推定を 行なった.

\section{2. 研究対象流域概要}

研究対象流域図を図一1に示す，大和川は近畿地方に 属し，淀川と紀ノ川の間に位置する一級河川で，奈良県 西部の笠置山地に源を発し，初瀬川渓谷を北西に流れ， 途中，奈良県の大和平野でいくつかの支川と合流しなが ら西へ流下し，生駒山地と金剛山地の切れ間で「亀の 瀬」と呼ばれる渓谷部を経て大阪平野に入り, 和泉山地 を源とする石川と合流し，さらに西へ流下して 2 支川と 


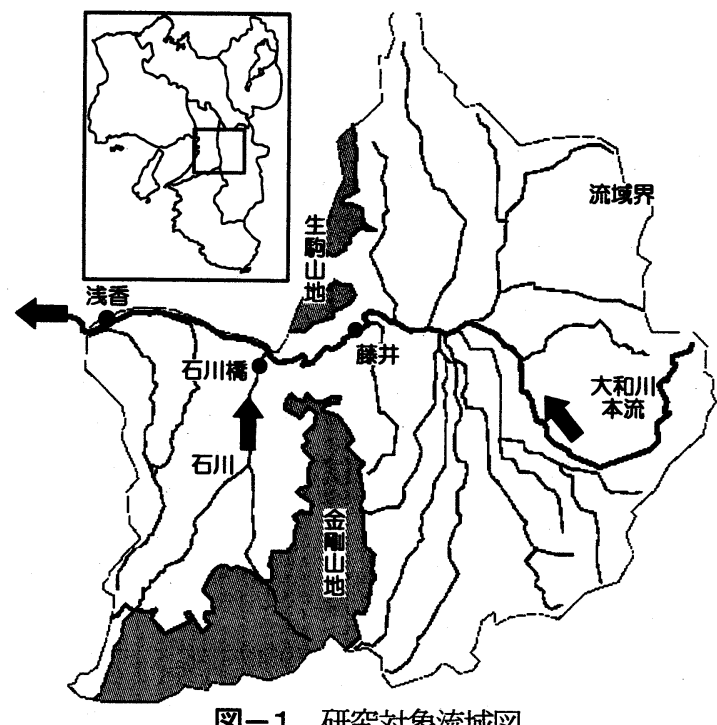

図-1 研究対象流域図

合流し，大阪湾へと注ぐ．年間降水量約 $1400 \mathrm{~mm}$ ，幹川流 路延長約 $68 \mathrm{~km}$ ，流域面積約 $1070 \mathrm{~km}^{2}$ ，流域人口約 214 万人 で, 奈良県, 南大阪地域の主要河川である. 研究対象地 域の土地利用分布は, 流域の東部から南部の河川の最上 流部においては森林が分布している. 奈良県側の大和平 野においては, 水田と住宅地が分布し, 大和川本流より 南側に位置する河川の流域においては, 中流部で住宅地 が密集しており, 大和川本流より北側の河川の流域にお いては上流から下流にかけて住宅地が分布している. 大 阪平野においては，石川流域の中流から下流の東側にお いて，水田や果樹園が広く分布するが，石川流域の中流 から下流の西側および石川より下流の 2 支川の流域にお いてはほとんどが住宅地である.

\section{3. 研究方法}

本研究は, 国土交通省近畿地方整備局大和川工事事務 所が所有する水質, 流量データを用いて研究を行なった. 水質, 流量データは1995年〜1999年の 5 年分を用いた. 観測地点は，図一 1 に示寸ように，大和川本流で奈良県 の最下流に位置する藤井, 大和川本流の最下流に位置す る浅香, そして, 支川である石川の最下流に位置する石 川橋の 3 地点である. また, 考察に用いた水質項目は, BOD, COD, 塩素イオン, 総リン, 硝酸態窒素, アンモニ ア態窒素の 6 項目である. 水質データの測定頻度は, 藤 井, 浅香のBOD, COD, 塩素イオン, 総リン, アンモニア 態窒素が毎月 1 回である. また, 半年に 1 回, 24 時間連 続測定 ( 2 時間毎に13回水質測定) も行なっている. 次に, 藤井, 浅香の硝酸態窒素と石川橋のBOD, COD, 塩素イオ ン, 総リン, アンモニア態窒素の測定頻度は毎月 1 回で, 石川橋の硝酸態窒素は 3 ヶ月に 1 回である．流量は，5 年間の日流量データを用いた.

\section{4. 結果と考察}

\section{（1）日物質移動量の算定方法の比較}

5 年間の平均の物質移動量を求める際に，流量と濃度 の積が物質移動量となるため, 流量と濃度の情報が必要 である.また，物質負荷量は，河川の測定地点から推定 される流域の面積, 人口などから計算される. ここで, 流量は毎日の観測データが存在するが, 水質データは 1 年に $4 \sim 12$ 日と年 2 回の 24 時間連続測定の分しかない. したがって，水質を測定していない日の濃度，または, 物質移動量を推定する必要がある. そこで，1995年から 1999年までの 5 年間での平均の物質移動量を算定するた めに 2 種類の方法が考えられる.

1つめは, 水質データが存在する日の日流量と濃度の 相関関倸から回帰式を導き，その式から，1日毎の濃度 を求め, 求めた 1 日毎の濃度に当日の日流量を乗じて, 1 日毎の物質移動量を求める. これを 5 年分積分して, 日あたりの物質移動量に換算する方法である.

2つめは, 水質データが存在する日の日流量と濃度を 乗じ, 先に各測定日の物質移動量を算定し, そして, 水 質データが存在する日の日流量と物質移動量の相関関係 から回帰式を導き，その式に 1 日毎に，5年分の日流量 を代入し, 求まった 1 日毎の物質移動量を積分して, 日 あたりの物質移動量に換算する方法である.

この 2 種類の算定方法を比較するために, 代表として, 図一2に, 藤井における日流量とCODの関係, 日流量と COD移動量の関係を示す. 日流量とCODの関係において, CODは流量の増加に伴ない減少しているが，その分布は 直線ではなく双曲線に近く, 相関関倸が判りにくい. 一 方, 日流量とCOD移動量の関係においては，COD負荷量は 日流量の増加に伴ない増加し, 日流量とCODの関係より 相関関係が見やすい．このことから, 物質移動量の算定 には，水質データが存在する日の日流量と物質移動量の 関係から回帰式を導く方法を適用する.

\section{（2）日物質移動量の算定}

日流量と物質移動量の関係から求めた回帰式を用いて, 藤井におけるCOD以外の物質についても日物質移動量を 計算した. 図一3〜 4に藤井における塩素イオン, 総リ ン, 硝酸態窒素, BOD, アンモニア態窒素の物質移動量 と日流量の関係を示す.

塩素イオン, 総リン, 硝酸態窒素の物質移動量と日流 量の関係においては，日流量の増加に伴ない，物質移動 量も増加する傾向にある. この原因としては, COD, 塩 素イオン, 総リン, 硝酸態窒素は主として, 流量依存性 が強いことがわかる，一方，BOD，アンモニア態窒素の 物質移動量と日流量の関係においては, 日流量が同じで も物質移動量が大きく変動し, また, 物質移動量が同じ でも日流量が変動し, 分布は直線上にない. この原因と 

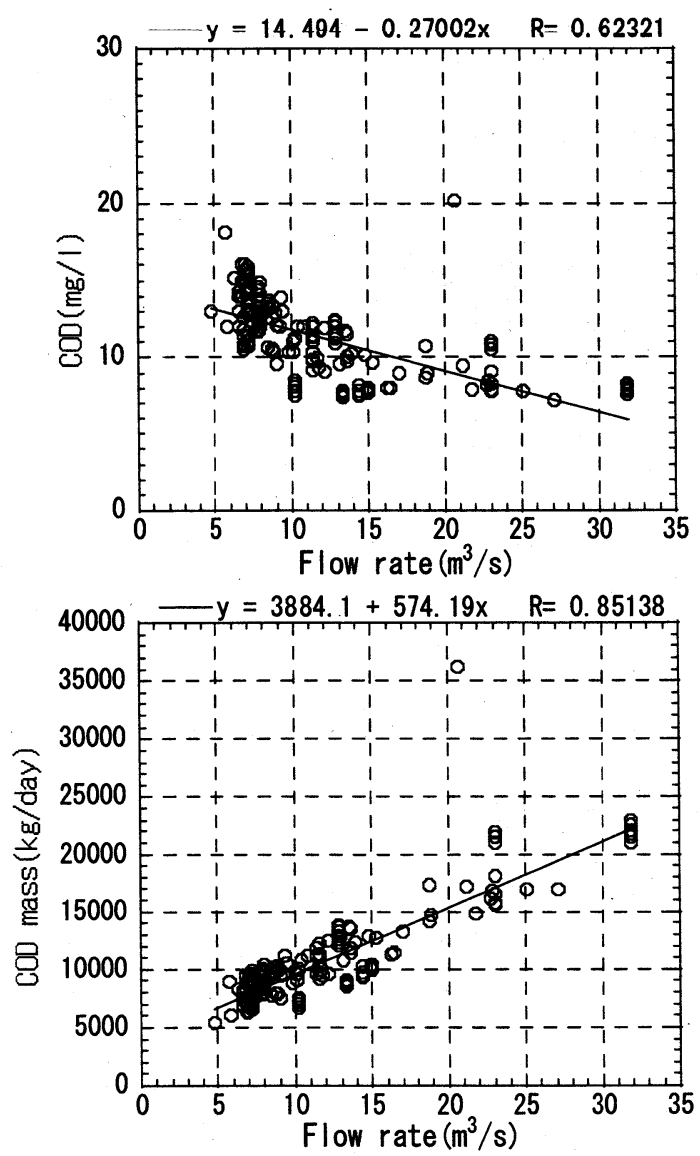

図一2 藤井における日流量とCOD，COD移動量の関係

しては, BOD，アンモニア態窒素については，河川水に よる希釈以外の効果が影響していると考えられる. 図一 4の分布を水温別にみると, BODは水温 $20^{\circ} \mathrm{C}$ 以上では, 流量が増加するとBOD移動量が増加する傾向にあるが, 水温 $20^{\circ} \mathrm{C}$ 未満では, BOD移動量が変化しても流量はほぼ 一定である. アンモニア態窒素の移動量は $20^{\circ} \mathrm{C}$ 以上では, 流量が変化してもほぼ一定で, $20^{\circ} \mathrm{C}$ 未満では, アンモニ ア態窒素移動量が変化しても流量はほぼ一定である.こ のことから，BOD，アンモニア態窒素移動量は, 水温に より移動量が変化する温度依存性があることがわかる. BOD，アンモニア態窒素に水温依存性がある理由は，BOD は有機物污濁を表わす指標であることから，微生物の有 機物分解活動が水温に影響すると考えられるためである。 また, アンモニウム態窒素は, 有機物が増加する(BODが 増加する）と，それに伴い有機物の分解物であるアンモ ニウム態窒素も増加すると考えられるためである.

よって, 藤井においては, CODを含め, 塩素イオン, 総リン，硝酸態窒素についてはこの算定方法が適用でき るが，BOD，アンモニア態窒素については水温依存性が あるため適用できない．

次に, 浅貃, 石川橋の各物質についても, この算定方 法の適用について検討した．表一 1 に浅香，石川橋にお けるCOD，塩素イオン，総リン，硝酸態窒素，BOD，アン モニア態窒素の物質移動量と日流量との相関係数を示す。 石川橋では, 藤井と同じく, COD, 塩素イオン, 総リン, 硝酸態窒素の物質移動量と流量との相関係数が比較的高
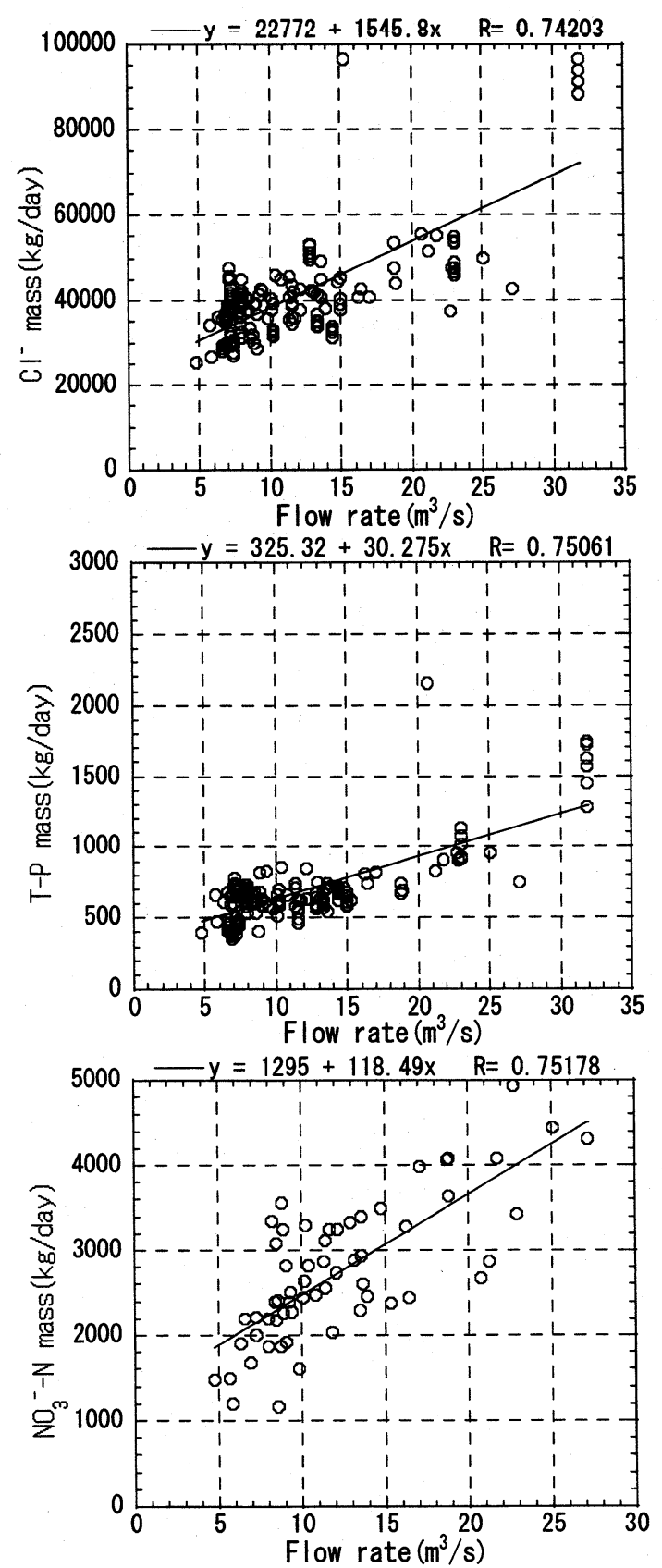

図一3 藤井における日流量と $\mathrm{Cl}^{-}, \mathrm{T}-\mathrm{P}, \mathrm{NO}_{3}^{-}-\mathrm{N}$ 移動量の関係

く，BOD，アンモニア態窒素の物質移動量と流量との相 関係数は低い，浅香では，COD，硝酸態窒素の物質移動 量の流量との相関係数が比較的高いが, 塩素イオン, 総 リン，BOD，アンモニア態窒素の物質移動量と流量との 相関係数は低い。このことから, 流量との相関係数が比 較的高い，台川橋UCOD，盐素イオン，総リン，硝酸態 窒素, 浅香のCOD, 硝酸態窒素は, 流量依存性が強いこ とがわかる. したがって，これらの物質については水質 データが存在する日の日流量と物質移動量の関係から回 帰式を導く方法により求められた物質移動量を用いる.

流量との相関が低い浅香，石川橋のBOD，アンモニア 態窒素は, 藤井と同様に, 水温により物質量が変化した ため、水温依存性の効果があると考えられる.

藤井や石川橋では流量との相関が高かった塩素イオン, 総リン移動量は, 浅香でのみ, 流量との相関係数が低 

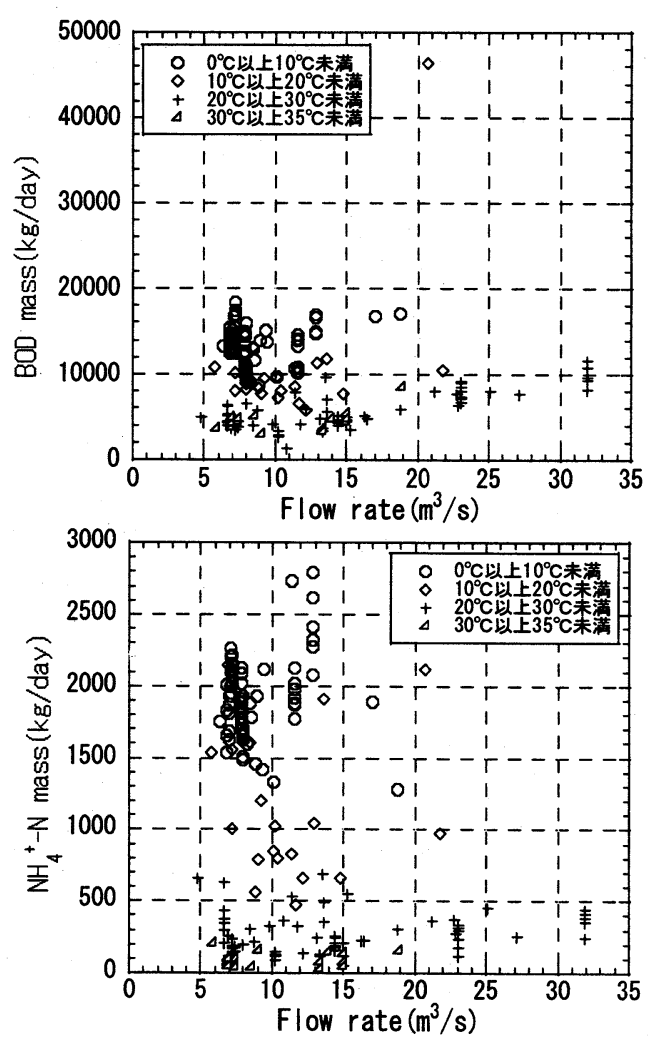

図-4 藤井における日流量とBOD, $\mathrm{NH}_{4}{ }^{+}-\mathrm{N}$ 移動量の関係

表-1 各地点の物質移動量の日流量との相関係数

\begin{tabular}{|c|r|r|r|}
\hline & \multicolumn{1}{|c|}{ COD移動量 } & \multicolumn{1}{c|}{$\mathrm{Cl}^{-}$移動量 } & \multicolumn{1}{c|}{$\mathrm{T}-\mathrm{P}$ 移動量 } \\
\hline 浅香 & 0.65916 & 0.44837 & 0.50298 \\
\hline 石川橋 & 0.75536 & 0.66596 & 0.70015 \\
\hline & $\mathrm{NO}_{3}{ }^{-}-\mathrm{N}$ 移動量 & $\mathrm{BOD}$ 移動量 & $\mathrm{NH}_{4}{ }^{+}-\mathrm{N}$ 移動量 \\
\hline 浅香 & 0.88542 & 0.15445 & 0.2961 \\
\hline 石川橋 & 0.95854 & 0.35175 & 0.02677 \\
\hline
\end{tabular}

かった. 図一5に浅香における塩素イオン, 総リンの物 質移動量と日流量の関係を示す．塩素イオン，総リンの 移動量は, 流量が $25 \sim 30 \mathrm{~m}^{3} / \mathrm{s}$ 以上になると，一定になる 傾向にある.このことから, 流量がある程度大きくなる と，より希釈の効果が強くなると考えられる. また，そ のデータが，全体の相関係数を小さくしていると考えら れる. しかし, 最下流の浅香においてのみ, 塩素イオン, 総リンの希釈の効果が強くみられるのかは現時点では不 明である. 最後に, 浅香の塩素イオン, 総リンの物質移 動量算定法の適用についてであるが，相関係数が低かっ たが，その原因は流量が大きくなると希釈の効果が大き くなるということで, 流量依存性が見られることから， 浅香の塩素イオン, 総リンについても, この物質移動量 算定法を適用する.

\section{（3）各流域の物質移動量の比較}

各地点の各物質の物質移動量を算定した後, 大和川流 域を奈良県，大阪府，石川流域，大阪府下流域，流域全 体の $5 つ に$ 分類し，各流域の物質移動量を比較した。 な お，各流域加らの物質移動量は，奈良県は奈良県内の大 和川最下流の藤井における物質移動量, 大阪府は大和川 最下流の浅香の物質移動量から藤井の物質移動量を減じ
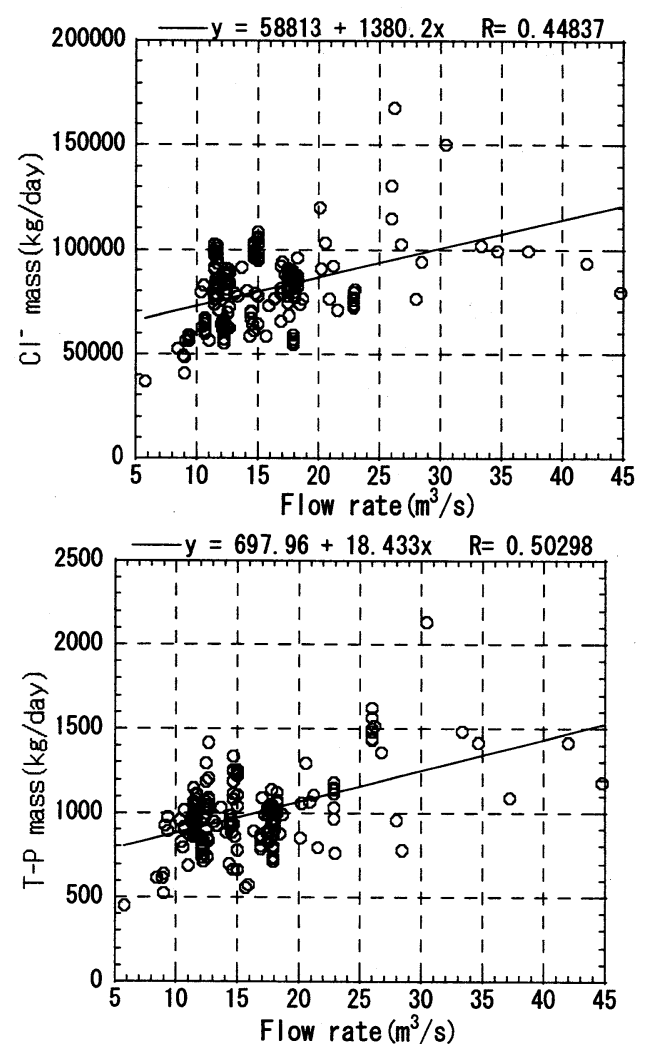

図一 5 浅香における日流量とCl-,T-P移動量の関係

たもの, 石川流域は石川最下流の石川橋における物質移 動量，大阪府下流域は浅香の物質移動量から藤井，石川 橋の物質移動量を減じたもの, 流域全体は浅香における 物質移動量を用いた. また，石川流域と大阪府下流域は 大阪府を二分したものである.

表一2に各流域の物質移動量を示す，なお，物質移動 量の算定には，洪水時の水質データがないために，結果 として約10～15\%の高流量時の流量データが含まれてい ない，そのため，洪水時などの高流量時における物質移 動量は，高流量時の水質データを含まない日流量と物質 移動量の相関から外挿した. COD, 塩素イオン, 総リン, 硝酸態窒素の移動量は，ともに，大阪府に比へ，奈良県 の方が多い. しかし, 塩素イオン, 硝酸イオンの移動量 は両流域での差は小さいが, COD, 総リンの物質移動量 は奈良県の方が格段に大きい，大阪府に比へ，奈良県の 方が物質移動量が多い原因は，表一3に示すように，奈 良県の流域面積が大阪府の流域面積の約 2 倍で, 奈良県 の方が面積が大きいためであると考えられる. 次に，大 阪府内で比較すると, COD, 塩素イオン, 総リン, 硝酸 態窒素の移動量はともに，大阪府下流域で格段に高い. この原因としては，表一3に示すように，大阪府下流域 は, 住宅地・建築物・道路面積が多く, また, 石川流域 は, 森林面積が多いことが考えられる.

\section{（4）物質負荷量の算定と考察}

各流域の物質移動量をその流域の人口，面積で除し， 各流域の単位人口, 単位面積あたりの物質負荷量を算定 し，考察した. 表一4に各流域からの単位人口および単 
表-2 各流域の物質移動量

\begin{tabular}{|l|r|r|r|r|}
\hline \multicolumn{1}{|c|}{ 単位: $\mathrm{kg} /$ day } & \multicolumn{1}{c|}{$\mathrm{COD}$} & \multicolumn{1}{c|}{$\mathrm{Cl}^{-}$} & $\mathrm{T}-\mathrm{P}$ & $\mathrm{NO}_{3}{ }^{-}-\mathrm{N}$ \\
\hline 奈良県(藤井) & 17837 & 60336 & 1061 & 4174 \\
\hline 大阪府(浅香-藤井 & 9040 & 45646 & 267 & 3103 \\
\hline 流域全体(浅香) & 26877 & 105981 & 1328 & 7277 \\
\hline 石川流域(石川橋) & 2197 & 12258 & 72 & 547 \\
\hline $\begin{array}{l}\text { 大阪府下流域(浅 } \\
\text { 香-藤井-石川橋) }\end{array}$ & 6842 & 33388 & 195 & 2556 \\
\hline
\end{tabular}

※物質移動量算定回帰式作成に用いた流量の最大流量を超 える日流量の存在割合 (=超過流量数 $/ 5$ 年間全日流量数)

藤井 : $14.6 \%$ 浅香 : $14.7 \%$ 石川橋 : $9.3 \%$

表一3 各流域における土地利用別面積

(カッコ内数字は各流域における土地利用割合)

\begin{tabular}{|c|c|c|c|c|c|}
\hline 単位: $\mathrm{km}^{2}(\%)$ & 面積 & 森林 & 水田 & $\begin{array}{l}\text { 畑地- } \\
\text { 果澍園 }\end{array}$ & $\begin{array}{l}\text { 䜃宅地·建 } \\
\text { 筑物·道路 }\end{array}$ \\
\hline 耍県(藤井) & $\overline{743}$ & $306(41.2)$ & & $33(4.4)$ & $169(22.8)$ \\
\hline & & & & & \\
\hline & 1069 & & & $52(4.9)$ & $262(24.5)$ \\
\hline & 220 & & & $13(5.9)$ & $1(14$. \\
\hline 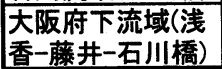 & 106 & 4(4.1) & $21(19.6)$ & 0.0 & \\
\hline
\end{tabular}

位面積あたりの物質負荷量を示す。

(a)COD

単位人口あたりのCOD負荷量は，流域全体では $12.6 \mathrm{~g} /$ 人/dayで, 流域別では奈良県からの方が大阪府からに比 べ多い. 単位人口あたりの負荷量は，生活排水起源で生 活習慣が大きく変化しなければ，流域が異なっても変化 しないと考えられる，また，下水道普及率は奈良県が $57.8 \%$, 大阪府が51.2\%で奈良県の方がやや高いがほぼ 同じである ${ }^{7)}$.このように，生活習慣や排水条件が同じ であるのに，奈良県の方が単位人口あたりのCOD負荷量 が高くなっていることから，奈良県の方が大阪府に比べ， 事業所などの生活排水以外からの排水の影響を強く受け ていると考えられる. 次に, 単位面積あたりのCOD負荷 量は，流域全体では $25.1 \mathrm{~kg} / \mathrm{km}^{2} / \mathrm{day}$ で, 流域別でみると 奈良県に比べ，大阪府の方が多い，先に述べたように， 下水道普及率けほぼ同じである，また，表一3から，奈 良県と大阪府の住宅地・建築物・道路面積を比較すると， 奈良県の方が多いが, 表一4から, 人口密度を計算する と, 奈良県では約 1655 人 $/ \mathrm{km}^{2}$, 大阪府では約 2791 人 $/ \mathrm{km}^{2}$ であることから，大阪府の方が人口密度が高いことが原 因と考えられる.

大阪府内での石川流域と大阪府下流域を比較すると， 単位人口あたりでは大阪府下流域からのCOD負荷量は, 石川流域の約 3.3 倍でかなり多い.このことから，大阪 府下流域では事業所から排出された有機物の影響を強く 受けていると考えられる. 単位面積あたりでも，大阪府 下流域のCOD負荷量は石川流域の約6.5倍でかなり多い. これは，表一3から，石川流域では森林面積が多く，住 宅地・建築物・道路面積が少なく, 大阪府下流域では, 森林面積が少なく, 住宅地・建築物・道路面積が多いこ とが原因と考えられる.

\section{(b)塩素イオン}

単位人口あたりの塩素イオン負荷量は，流域全体では $49.5 \mathrm{~g} /$ 人/dayで，流域別では，奈良県と大阪府はほぼ同
表-4 単位人口, 単位面積あたりの物質負荷量

\begin{tabular}{|c|c|c|c|c|c|}
\hline 単位: $g /$ / /day & 人口(人) & COD & $\mathrm{Cl}^{-}$ & $T-P$ & $\mathrm{NO}_{3}^{-}-\mathrm{N}$ \\
\hline 奈良県(藤井) & 1230000 & 14.5 & 49.1 & 0.9 & \begin{tabular}{|l}
3.4 \\
\end{tabular} \\
\hline 大阪府(浅香-藤井) & 910000 & 9.9 & 50.2 & 0.3 & 3.4 \\
\hline 流域全体(浅香) & 2140000 & 12.6 & 49.5 & 0.6 & 3.4 \\
\hline 石川流域(石川橋) & 70000 & 4.7 & 26.1 & 0.2 & 1.2 \\
\hline $\begin{array}{l}\text { 大阪府下流域(浅 } \\
\text { 香-藤井-石川橋) }\end{array}$ & 440000 & 15.6 & 75.9 & 0.4 & 5.8 \\
\hline 単位: $\mathrm{kg} / \mathrm{km}^{2} /$ day & 面積 $\left(\mathrm{km}^{2}\right)$ & COD & $\mathrm{Cl}^{-}$ & $T-P$ & $\mathrm{NO}_{3}^{-}-\mathrm{N}$ \\
\hline 奈食県(藤井) & 743 & 24.0 & 81.2 & 1.4 & 5.6 \\
\hline 阪府(浅香-藤井) & 326 & 27.7 & 140.0 & 0.8 & 9.5 \\
\hline 域全体(浅香) & 1069 & 25.1 & 99.1 & 1.2 & 6.8 \\
\hline 石川流域(石川橋) & 220 & 10.0 & 55.7 & 0.3 & 2.5 \\
\hline $\begin{array}{l}\text { 大阪府下流域(浅 } \\
\text { 香-磷－石-橋) }\end{array}$ & 106 & 64.6 & $315 . C$ & 1.8 & 24.1 \\
\hline
\end{tabular}

じ値である．このことから，塩素イオンの負荷は，産業 活動よりも，家庭からの生活排水の影響が大きいと考え られる。また，単位面積あたりの塩素イオン負荷量は， 流域全体では99. $1 \mathrm{~kg} / \mathrm{km}^{2} /$ dayで，流域別でみると，奈良 県に比べ，大阪府の方が多い。これは，COD同様，奈良 県に比べ大阪府の方が，人口密度が高いことが原因と考 えられる。

次に，大阪府内での石川流域と大阪府下流域を比較す ると，単位人口あたりでは大阪府下流域からの塩素イオ ン負荷量は, 石川流域の約 3 倍でかなり多い. このこと から，大阪府下流域では事業所からの排水が塩素イオン 負荷量を大きくしていると考えられる．単位面積あたり でも，大阪府下流域の塩素イオン負荷量は石川流域の約 5.6倍でかなり多い.これは，COD同様，表一3から，石 川流域では森林面積が多く，住宅地・建築物・道路面積 が少なく, 大阪府下流域では, 森林面積が少なく, 住宅 地・建築物・道路面積が多いことが原因と考えられる.

(c)総リン

単位人口あたりの総リン負荷量は, 流域全体では $0.6 \mathrm{~g} /$ 人/dayで，流域別では奈良県からの方が大阪府か らに比べ多い. 生活排水起源で生活習慣が大きく変化し なければ，流域が異なっても変化しないと考えられ，さ らに下水道普及率は奈良県と大阪府でほぼ同じであるた め，生活排水以外の原因が影響していると考えられる. また，単位面積あたりの負荷量も，大阪府に比べ，奈良 県の方が多い, 表一3から, 水田, 畑地・果樹園といっ た農地と住宅地・建築物・道路の面積が，ともに，大阪 府に比べ，奈良県の方が多いため，農地と事業所の両方 が原因と考えられるが，表一4から，人口密度を計算す ると, 奈良県では約 1655 人 $/ \mathrm{km}^{2}$, 大阪府では約 2791 人/ $\mathrm{km}^{2}$ で，人口密度の低い奈良県の方が総リン負荷量が多 くなっていることから，大阪府に比べ，奈良県の総リン 負荷量が大きい原因は，水田，畑地・果樹園といった農 地からの排水が影響していると考えられる.

次に，大阪府内での石川流域と大阪府下流域を比較す ると，単位人口あたりでは，石川流域と大阪府下流域で ほぼ同じである．このことから，総リンの負荷は，産業 活動よりも，家庭からの生活排水の影響が大きいと考え られる．単位面積あたりでは，大阪府下流域の総リン負 
荷量は石川流域の6倍でかなり多い。これは，表一3か ら, 石川流域では森林面積が多く, 住宅地・建築物・道 路面積が少なく, 大阪府下流域では, 森林面積が少なく, 住宅地・建築物・道路面積が多いことが原因と考えられ る.

\section{(d)硝酸態窒素}

単位人口あたりの硝酸態窒素負荷量は，流域全体では $3.4 \mathrm{~g} /$ 人/dayで, 流域別では大阪府, 奈良県ともに $3.4 \mathrm{~g} /$ 人/dayで同じであった．単位人口あたりでは，生活排水 起源の物質移動量は生活習慣が大きく変化しなければ, 流域が異なっても変化しないと考えられるため, 硝酸態 窒素の負荷は事業所からよりも, 生活排水からの方が大 きいと考えられる. 次に, 単位面積あたりの硝酸態窒素 量は，流域全体では6. $8 \mathrm{~kg} / \mathrm{km}^{2} /$ day ゙, 流域別では奈良 県に比べ大阪府の方が大きい. 硝酸態窒素は住宅地から だけでなく，農地からも排出される ${ }^{8)}$ が，水田，畑地・ 果樹園の面積は, 奈良県に比べ, 大阪府の方が小さい. しかし，人口密度は奈良県に比べ大阪府の方が高い。こ のことから, 人口密度の影響(生活排水)で, 大阪府の単 位面積あたりの硝酸態窒素負荷量が奈良県に比べ大きく なっていると考えられる.

次に，大阪府内での石川流域と大阪府下流域を比較す ると，単位人口あたりでは大阪府下流域からの硝酸態窒 素負荷量は, 石川流域の約 5 倍である. このことから, 大阪府下流域では事業所からの排水が硝酸態窒素負荷量 を大きくしていると考えられる. 単位面積あたりでも， 大阪府下流域の硝酸態窒素負荷量は石川流域の約10倍で かなり多い，これは，表一3から，石川流域では森林面 積が多く, 住宅地・建築物・道路面積が少なく, 大阪府 下流域では，森林面積が少なく，住宅地・建築物・道路 面積が多いことが原因と考えられる.

\section{5. まとめ}

1995年〜1999年の 5 年分の流量, 水質データを用いて, 平均的な物質移動量の推定を行なった結果, COD, 塩素 イオン, 総リン, 硝酸態窒素は, 流量が増加すると物質 移動量も増加するといった流量依存性が見られたことか ら，流量と物質移動量の関係から得られた回帰式に 5 年 分の日流量を代入し毎日の物質移動量を求め, それを積 分し，日あたりに換算する方法で，日物質移動量を算定 することができた．しかし，BOD，アンモニア態窒素は， 流量依存性が見られず，水温が高いと濃度が低く，水温 が低いと濃度が高くなる水温依存性が見られたことから 日物質移動量を算定することができなかった.

各流域の物質移動量は, COD, 塩素イオン, 総リン, 硝酸態窒素とも奈良県が多く, 流域面積が大きいことが 原因と考えられた．また，大阪府内では，大阪府下流域 で, COD, 塩素イオン, 総リン, 硝酸態窒素の移動量が
格段に多く，住宅地等の面積が大きいことが原因と考え られた.

物質移動量から算定した物質負荷量より，単位人口あ たりでは, COD負荷量は奈良県, 大阪府下流域で高く, 生活習慣が大きく変化しなければ，流域が異なっても変 化せず，また，下水道普及率もほぼ同じであったことか ら，事業所からの有機物負荷が大きいと考えられた．塩 素イオン, 硝酸態窒素は, 負荷量が大阪府, 奈良県とも ほぼ同じであったため, 生活排水起源と考えられたが, 大阪府内では，大阪府下流域の方が石川流域に比べて高 く，事業所からの負荷が大きいと考えられた． 総リンは, 農地面積が多く, 人口密度の低い奈良県で負荷量が高い ことから農地排水起源と考えられた。 しかし，大阪府内 では，大阪府下流域と石川流域でほぼ同じであったため， 生活排水起源と考えられた。単位面積あたりでは，COD， 塩素イオン, 硝酸態窒素の負荷量は, 奈良県に比べ大阪 府の方が多く, 大阪府の人口密度が高いことが原因と考 えられた. 総リンは農地面積が多く, 人口密度の低い奈 良県で負荷量が高いことから農地排水起源と考えられた。 大阪府内では，COD，塩素イオン，総リン，硝酸態窒素 の負荷量は大阪府下流域で大きく，住宅地等の面積が多 いことが原因と考えられた。

\section{参考文献}

1）環境省 : 平成11年度公共用水域水質測定結果, http://www. env.go.jp/water/suiiki_h11/index.html, 2000.

2）国土交通省河川局 : 平成12年全国一級河川の水質現況 2. 河川(湖沼等を含む)の水質, http://www.mlitgo.jp/kisha/kish a01/05/050726/050726_3_html, 2001.

3）国土交通省近畿地方整備局大和川工事事務所 : 大和川水質 データ<大和川の水質動向>, http://www.yamato.moc.go.jp YYKNET/kireini/d_02_chtml

4）平田健正 - 井伊博行 - 長谷部正彦・江種伸之 ・坂本康 - 条 川高徳・西山幸治・酒井信行・岩崎宏和 : 土地利用特性の 河川水質に及ぼす影響一大阪府石川流域一, 土木学会論文 集, No.614/II-46, pp. 97-107, 1999.

5）井伊博行 - 平田健正 - 長谷部正彦・江種伸之 - 坂本康 - 条 川高徳・西山幸治・酒井信行・堀井壮夫 : 環境同位体及び 化学組成からみた石川流域の河川水と地下水の起源につい て, 水工学論文集, 第43巻, pp. 205-210, 1999.

6）窪原拓馬 - 井伊博行 - 平田健正 - 江種伸之 - 石塚正秀 - 伊 勢達男・宮川勇二 : 大和川流域における河川水の水質特性 について, 水工学論文集, 第45巻, pp. 985-990， 2001.

7）応用地質株式会社 : 大和川流域水質保全検討(その2)業務 報告書, 2001 .

8）井伊博行-平田健正・松尾宏 - 田瀬則雄 - 西川雅高 : 茶畑 施肥に由来する硝酸性窒素と周辺表流水に及ぼす影響, 水 工学論文集, 第41巻, pp. 575-580, 1997.

（2001. 10.1受付） 